\title{
CREDIT INTERMEDIARIES' REGULATION AND PROFITABILITY: THE ITALIAN CASE OF D.LGS. NO. 141/2010
}

\author{
Nicola Bianchi ${ }^{*}$, Umberto Filotto ${ }^{* *}$, Xenia Scimone ${ }^{* * *}$ \\ * Organismo Agenti e Mediatori, Italy \\ ** University of Rome Tor Vergata, Italy \\ *** Corresponding author, University of Rome Tor Vergata, Italy \\ Contact details: University of Rome Tor Vergata, Via Columbia 3, 00133 Rome (RM), Italy
}

\section{OPEN ACCESS}

How to cite this paper: Bianchi, N., Filotto, U., \& Scimone, X. (2020). Credit intermediaries' regulation and profitability: The Italian case of D.Lgs. No. 141/2010. Risk Governance and Control: Financial Markets \& Institutions, 10(2), 71-78.

http://doi.org/10.22495/rgcvl0i2p6

Copyright $@ 2020$ The Authors

This work is licensed under a Creative Commons Attribution 4.0 International License (CC BY 4.0).

https://creativecommons.org/licenses/ by/4.0/

ISSN Online: 2077-4303

ISSN Print: 2077-429X

Received: 23.05 .2020 Accepted: 06.07.2020

JEL Classification: G2, L8, M2 DOI: $10.22495 /$ rgcvl0i2p6

\begin{abstract}
This work studies the effect of Italian regulation D.Lgs. No. 141/2010 (Law 141), introduced to transpose Directive 2008/48/EC of the European Parliament into the performance of credit intermediaries. Law 141's entry into force provides an opportunity to study the effect of greater market entry barriers on sector profitability. The Italian case is particularly significant because it is characterized by strict application of the directive, a low level of financial literacy, and a distribution model that, for some kinds of personal loans, allows agents and brokers a significant role (Canales \& Nanda, 2012). We study a panel of Italian agents and credit brokers, using a panel and difference-in-differences regression. The results show that, from 2009 to 2017, firm profitability was driven not by the increase in market entry requirements introduced by Law 141 but, rather, by firms' size, efficiency, and business model.
\end{abstract}

Keywords: Agent, Credit Broker, Competition, Barriers

Authors' individual contribution: Conceptualization - N.B., U.F., and X.S.; Methodology - N.B., U.F., and X.S.; Software - N.B.; Validation - N.B. and U.F.; Formal Analysis - N.B.; Resources - U.F. and X.S.; Data Curation - N.B. and X.S.; Writing - Original Draft - N.B. and X.S.; Writing - Review \& Editing - N.B., U.F., and X.S.; Visualization - N.B.; Supervision - U.F.; Project Administration - U.F.; Funding Acquisition - U.F.

Declaration of conflicting interests: The Authors declare that there is no conflict of interest.

Acknowledgements: We thank John Manley, Jay Kang, Pavel Štrach, Carlos Trejo-Pech, Fadi Fawaz, Peter Cincinelli, Giovanna Zanotti, and the participants of the 19th International Business and Economic Conference for their comments.

\section{INTRODUCTION}

This work studies the effect of Italian regulation D.Lgs. No. 141/2010 (Law 141) on the performance of credit intermediaries. This new regulation was introduced to transpose Directive 2008/48/EC of the European Parliament into law. It was approved to harmonize the substantial differences between the laws of the various member states in the field of credit for natural persons in general and consumer credit in particular... [to] ensure that all consumers in the Community enjoy a high and equivalent level of protection of their interests and to create a genuine internal market. (Gathergood, 2012).

Indeed, consumer credit targets clients with a lower average income that could "suffer income shocks, credit withdrawals and unforeseen expenses on durables" and, furthermore, who "make greater use of quick-access but high-cost credit items such as store cards and payday loans" (Gathergood, 2012, p. 590). 
To achieve its goal in the unique sector of credit intermediaries, the directive created new operating rules and requirements for credit agents and brokers. According to the directive, a credit intermediary is a natural or legal person who is not acting as a creditor and who 1) presents or offers credit agreements to consumers; 2) assists consumers by undertaking preparatory work in respect of credit agreements other than as referred to in (1) or 3 ) concludes credit agreements with consumers on behalf of the creditor.

The directive requires such subjects to be transparent in the offer's disclosure, limits remuneration practices and asks the member states to create national authorities to control these intermediaries. Many countries, such as Italy, have gone beyond the directive and introduced further professional and financial requirements for credit intermediaries.

Law 141 introduces all the content of the directive and adds new requirements for credit sector operators in terms of capitalization and professionalism (e.g., a competency exam). Furthermore, it creates a new authority to supervise the sector - the Organismo Agenti e Mediatori (OAM) financed by fees applied to the operators themselves.

We want to test the effect of Law 141 on credit intermediaries in Italy. Law 141 could have two effects on companies' returns:

H1: Law 141 could increase costs and thus reduce profits; that is, the new regulation's increased requirements for credit intermediaries will result in higher production costs.

H2: Law 141 could increase the added value and returns of credit offers, that is, the new regulation creates entry barriers to the sector and requires higher standards of operator professionalism, which will result in higher prices for credit intermediary services.

In particular, the second potential effect could have two different drivers. First, since D.Lgs. No. 141/2010 introduces new entry requirements for market operators, their entry could be limited, creating an oligopoly that can increase market prices (Bulow, Geanakoplos, \& Klemperer, 1985). Second, the new regulation, by raising the level of professionalism of operators, could increase the quality of services offered by credit intermediaries, as well as their prices.

We determine which of the two effects Law 141 produces and, in the case of a positive effect, if the driver is the increase in professionalism or the creation of an oligopoly. To test our hypothesis, we study the effect of the new regulation on a panel of Italian agents and CBs enrolled in the new register created by Law 141. Since firm size seems to play an important role in explaining performance, we also repeat the analysis by splitting our sample into agents and CBs and then categorizing each subsample by total assets. This approach allows us to determine if the results change according to company characteristics. To test the robustness of the results, we also run a difference-in-differences (DiD) regression, using as the untreated group those agents and CBs in operation before the new regulation was instituted but who did not enroll in the new registers. Furthermore, we check if the same performance drivers play a role before and after Law 141's reform, or if only their indirect effects are involved.
Our study focuses on Italy because it provides an interesting experimental setting that distinguishes itself by strict application of the directive (through Law 141) and its particular impact on financial inclusion: credit intermediaries have played a historical role in Italy, and the country has one of the lowest average levels of financial literacy in Europe.

The remainder of this paper is organized as follows. Sections 2 and 3 describe the methodology and the results, respectively. Section 4 presents our robustness checks, and Section 5 draws our conclusions.

\section{LITERATURE REVIEW}

Agents and credit brokers (CBs) merit attention because guaranteeing access to credit to clients who are "hardly bankable" is a strategic move. Lower financial literacy levels and greater geographical distances from large centers' effect is to limit the financial inclusion of small and medium-sized enterprises (Canales \& Nanda, 2012) and consumers (Alessandri \& Bottero, 2017) or drive them to overindebtedness (Crossney, 2017). Credit intermediaries could, therefore, supply credit to those customers who require a more personal offer (Cannari, Pagnini, \& Rossi, 2010; Uchida, Udell, \& Yamori, 2012; Fu, Dong, Liu, \& Han, 2016; Conklin, 2017). Furthermore, the credit intermediary sector is an important one. In 2018, this market had a value of about 248 million euros, considering only CBs. It also allows banks to be more efficient in distributing credit along the supply chain, now that they are decreasing their investments in local branches (Del Prete, Pagnini, Rossi, \& Vacca, 2017).

Law 141 is still the center of much debate (Demyanyk \& Loutskina, 2016; De Muynck \& Bruloot, 2017) and very limited literature exists on the topic "regulators" are focusing on the need for stricter rules on agents' remuneration, which could push market operators to sell more credit than clients can handle (Ambrose \& Conklin, 2014; Gete \& Gómez, 2015; Li, Hermes, \& Meesters, 2019). On the other hand, sector operators state that the new rules could negatively affect the market's profitability, which has already been reduced by the directive's reform. Contributing to the former perspective, this study tests whether the new regulation has had a negative impact on the sector's profitability. We thus contribute to the discussion by determining whether there is a significant negative association between the regulation's entry into force and firm profitability.

This work provides new empirical evidence on the literature linking regulation to intermediaries' profitability, filling an existing gap. Indeed, existing literature has not a clear result and mainly focuses on banking law. Pasiouras, Tanna, and Zopounidis (2009) use stochastic frontier analysis to provide international evidence that "banking regulations that enhance market discipline and empower the supervisory power of the authorities increase both cost and profit efficiency of banks". Wei, Gong, and $\mathrm{Wu}$ (2017) study "the impacts of the Net Stable Funding Ratio (NSFR) requirement on banks' choices of debt maturity and asset structures, with consequences for banks' profitability and social welfare" and their main results shows that just under certain conditions, the requirement may reduce 
banks' observed profits. Too strict regulation can sometimes "result in unintended consequences, such as driving a larger share of activity into the shadow banking sector" (p. 34) as demonstrated by Moloi (2014). On the other hand, some studies underline how sometimes stricter regulation can increase profitability; Mashamba (2018) results show that "regulatory pressure stemming from Liquidity Coverage Ratio requirement increased instead of diminishing the profitability of banks in emerging markets" (p. 34)

\section{RESEARCH METHODOLOGY}

We are interested in the regulation's impact on the profitability of credit intermediaries. We thus need a sample of firms that were active before and after the entry into force of D.Lgs. No. 141/2010. Before the 2010 regulation, agents and CBs had to enroll in a register maintained by the Italian central bank, the Bank of Italy (BI). A new OAM register was then instituted in its place. Our sample selection could have comprised firms enrolled in BI's register that were also enrolled in the OAM register in 2013, but this approach would create two problems. First, it would exclude companies that took the time to adequately comply with the new regulation and enrolled only in 2014; second, it would exclude firms cancelled from BI's list in 2011 and 2012 because they were waiting for the new regulation's implementation. We, therefore, select firms that enrolled in BI's register before 2009 and in OAM's register before 2015 as an "agent engaging in financial activities" (agente in attività finanziaria, or agent) or as a broker (mediatore, or CB).

The panel includes data from 2009 to 2017, with balance sheet data from AIDA, Gross Domestic Product (GDP) data from the Italian National Institute of Statistics (https://www.istat.it), and loan data from BI. Since firms could have changed the sector during the sample period, we include for each firm only the balance sheet data for the period it was registered. Table 1 shows descriptive statistics of the main variables.

We compute the tolerance (the inverse of the variance inflation factor, or $1 / \mathrm{VIF}$ ) after running a simple ordinary least squares regression of the return on equity ( $R O E$ ) variable, $R O E$, on the main variables to test the degree of collinearity. The results are reported in Table 2 . The levels of collinearity between the variables are not worrisome since they are significantly higher than 0.1 .

Table 1. Descriptive statistics

\begin{tabular}{|l|c|c|c|c|c|c|}
\hline & $\boldsymbol{N}$ & Mean & SD & Median & Max. & Min. \\
\hline$D_{141}$ & 6,736 & 0.537 & 0.499 & 1.000 & 1.000 & 0.000 \\
\hline ROE & 6,736 & 0.081 & 0.448 & 0.075 & 0.890 & -1.080 \\
\hline $\ln T A$ & 6,736 & 5.494 & 1.060 & 5.456 & 7.470 & 3.474 \\
\hline CO/INC & 6,736 & 0.992 & 0.302 & 0.941 & 1.942 & 0.584 \\
\hline WS/SRV & 6,736 & 0.413 & 0.494 & 0.230 & 1.833 & 0.000 \\
\hline GDP & 6,736 & -0.005 & 0.022 & 0.006 & 0.017 & -0.055 \\
\hline LNFM & 6,736 & 0.025 & 0.060 & 0.011 & 0.177 & -0.045 \\
\hline
\end{tabular}

Table 2. Tolerance tests

\begin{tabular}{|l|c|c|}
\hline & VIF & I/VIF \\
\hline$D_{141}$ & 1.18 & 0.85 \\
\hline InTA & 1.02 & 0.98 \\
\hline$C O / I N C$ & 1.03 & 0.97 \\
\hline WS/SRV & 1.01 & 0.99 \\
\hline$G D P$ & 1.40 & 0.81 \\
\hline$L N F M$ & 1.24 & 0.72 \\
\hline
\end{tabular}

We estimate the relation between the change in regulation and firm profitability by using the following panel regression with fixed effects, controlling for the size, efficiency, and business model of the credit intermediaries:

$$
\begin{gathered}
R O E_{i, t}=\alpha+\beta_{1} D_{i, t}^{141}+\beta_{2} \operatorname{lnT} A_{i, t}+\beta_{3} C O / I N C_{i, t}+\beta_{4} W S / S R V_{i, t}+\beta_{5} G D P_{t}+\beta_{5} L N F M_{t}+ \\
+\sum_{e \in(5,10,20,>20)} \delta^{e} D_{i, t}^{e}+\sum_{y \in(2009,2017)} \delta^{y} D_{t}^{y}+\varepsilon
\end{gathered}
$$

where, for firm $i$ in year $t, R O E_{i, t}$ is the ROE; $D_{i, t}^{141}$ is a dummy that takes the value of one after 2012; $\operatorname{lnTA}$ is the natural logarithm of total assets; CO/INC is the ratio between the total cost and value of production, and $W S / S R V$ is the ratio of total salaries to service costs. Table 3 defines all the variables. 
Table 3. Variables description

\begin{tabular}{|c|c|c|c|}
\hline Name & Symbol & Description & Source \\
\hline 141 Dummy & $\mathrm{D}_{141}$ & $\begin{array}{l}\text { dummy with value equal } 1 \text { after } 2012 \\
\text { and } 0 \text { before }\end{array}$ & \\
\hline Return on Equity & ROE & net revenues on total equity & author's elaboration on AIDA data \\
\hline Total Assets & $\operatorname{lnTA}$ & natural logarithm on total asset & author's elaboration on AIDA data \\
\hline Cost on Income & $\mathrm{CO} / \mathrm{INC}$ & total cost on total production's value & author's elaboration on AIDA data \\
\hline Wages on Services & WS/SRV & $\begin{array}{c}\text { cost for wages and salaries on cost } \\
\text { for services } \\
\end{array}$ & author's elaboration on AIDA data \\
\hline Gross Domestic Product & GDP & $\begin{array}{l}\text { yearly gross domestic product's growth } \\
\text { adjusted for inflation }\end{array}$ & author's elaboration on ISTAT data \\
\hline Loans-to-Family & LNFM & $\begin{array}{l}\text { yearly loans-to-families' growth adjusted } \\
\text { for inflation }\end{array}$ & author's elaboration on Bank of Italy data \\
\hline Firm's Dummies & $D^{(5,10,20,>20)}$ & $\begin{array}{c}\text { dummies with a value equal } 1 \text { if the firm } \\
\text { has been active in the sector for } 1 \\
\text { to } 5 \text { years, } 6 \text { to } 10 \text { years, } 11 \text { to } 20 \text { years, } \\
\text { or more than } 20 \text { years } \\
\text {. }\end{array}$ & \\
\hline
\end{tabular}

The last three regressors allow us to control for, respectively, a company's size, efficiency, and business model. To address possible endogeneity concerns due to the economic cycle, we include the yearly growth rates of the GDP and loans to families, GDP, and $L N F M$, respectively. Moreover, we control for firm experience in the market with a series of dummy variables $D_{i, t}^{e}$ that take the value of one if the firm has been active in the sector for 1 to 5 years, 6 to 10 years, 11 to 20 years, or more than 20 years, respectively. Finally, we included year fixed effects $D_{t}^{y}$.

Table 4 tests whether the new regulation's effects differ according to company type, we repeat the regression in equation(1), but we split the sample into agents and CBs. To do so, we consider only the firm's first choice recorded in the OAM register, cancelled all companies that changed from agent to $\mathrm{CB}$ or vice versa during the sample period.

To further test our results, we perform a DiD analysis. The untreated group consists of those companies that enrolled in BI's register but not in OAM's register, while the treated group is the same as in the previous regression. The definitions of the two samples are subject to two possible limits. First, in the transition from one register to the other, companies could have changed their fiscal code. This would mean that some companies that are defined as untreated could also appear in the treated sample. Second, since the requirements to be in BI's register were extremely loose, some firms could have been registered not because they were systematically acting as an agent or broker, but just because they were interested in possible sporadic business. This would cause the untreated sample to be extremely heterogeneous and not comparable with the treated sample. To address the first problem, we keep in the two subsamples only companies that did not go bankrupt during the sample period, which excludes all companies that changed their fiscal code during this time. To overcome the second problem, we keep in the untreated group only those companies with an Ateco 2007 code of 661922, which corresponds to "financial product agents, brokers, and intermediaries" (agenti, mediatori, and procacciatori in prodotti finanziari), excluding companies that were not systematically acting as agents or CBs before 2013. It is shown in Table 6 .

\section{RESULTS}

With the aim to evaluate if Law 141 could increase costs and thus reduce profits, we show that Law 141 did not have a significant negative impact on firm profitability. Table 2 shows the results of the model in equation (1). In column (1), we include $D_{i, t}^{141}$ as an independent variable and a constant term. The effect of Law 141 is negative, meaning that the new regulation's entry into force is associated with a decrease in sector profitability, but it is no longer significant after the addition of other controls. In column (2), we add firm-specific controls for firms' size $(\ln T A)$, efficiency $(C O / I N C)$, business model $(W S / S R V)$, and years of experience $\left(D_{F Y}\right.$ $D_{10 \text { Yехp }}$, and $\left.D_{\text {20Yехр }}\right){ }^{1}$ We find the $D_{i, t}^{141}$ values to still be negative but of smaller absolute value and not significant. This effect persists when we also control for the economic cycle (GDP) and the credit cycle (LNFM) in column (3), as well as when we add year fixed effects in column (4).

The results in Table 4 show that firms' size, efficiency, and business model have a greater impact on profitability than Law 141, significant and with a large absolute value in all the regressions. Column (4) shows that a $10 \%$ increase in firm size (measured by $\ln T A$ ) results in an average increase of $0.44 \%$ of the $R O E$, half of the $R O E$ average. Looking at firm efficiency, we find that a $10 \%$ decrease in costs on income results in an increase of $5 \%$ in the average ROE. Finally, the firm's business model is associated with returns: the use of external resources and collaborators is more profitable than relying on internal employment. We find that lower values of total salaries over service costs (WS/SRV) increase returns; a drop of $10 \%$ increases the $R O E$ by $0.8 \%$.

The variable $D_{>20 Y \exp }$ is omitted because of collinearity. 
Table 4. Effects of Law 141 on sector profitability

\begin{tabular}{|c|c|c|c|c|}
\hline & (1) & (2) & (3) & (4) \\
\hline \multirow{2}{*}{$D_{141}$} & $-0.057 * * *$ & -0.018 & -0.024 & -0.019 \\
\hline & [0.012] & {$[0.014]$} & {$[0.014]$} & {$[0.204]$} \\
\hline \multirow{2}{*}{$\ln T A$} & & $0.044 * * *$ & $0.046^{* * * *}$ & 0.049 * \\
\hline & & {$[0.015]$} & {$[0.015]$} & {$[0.015]$} \\
\hline \multirow{2}{*}{$C O / I N C$} & & $-0.527 *$ & -0.524 * & $-0.515^{*} * *$ \\
\hline & & {$[0.036]$} & {$[0.036]$} & {$[0.036]$} \\
\hline \multirow{2}{*}{$W S / S R V$} & & $-0.091 \%$ & $-0.089 * \ldots *$ & $-0.089 * * *$ \\
\hline & & {$[0.018]$} & {$[0.018]$} & {$[0.018]$} \\
\hline \multirow{2}{*}{$D_{\text {5Yexp }}$} & & -0.017 & -0.016 & 0.009 \\
\hline & & {$[0.054]$} & {$[0.055]$} & [0.063] \\
\hline \multirow{2}{*}{$D_{\text {loYexp }}$} & & -0.026 & -0.025 & -0.006 \\
\hline & & [0.048] & {$[0.048]$} & {$[0.054]$} \\
\hline \multirow{2}{*}{$D_{\text {20Yехp }}$} & & -0.017 & -0.017 & -0.007 \\
\hline & & {$[0.041]$} & {$[0.041]$} & [0.043] \\
\hline \multirow{2}{*}{$G D P$} & & & -0.128 & -0.357 \\
\hline & & & {$[0.248]$} & [2.966] \\
\hline \multirow{2}{*}{$L N F M$} & & & $0.378 * * *$ & 0.032 \\
\hline & & & {$[0.082]$} & [0.122] \\
\hline \multirow{2}{*}{ Cost. } & $0.108^{* * * *}$ & $0.429 * * *$ & $0.408 * * *$ & $0.404 * *$ \\
\hline & {$[0.007]$} & [0.103] & {$[0.102]$} & [0.190] \\
\hline$N$ & 6,927 & 6,736 & 6,736 & 6,736 \\
\hline$R^{2}$ & 0.01 & 0.13 & 0.14 & 0.14 \\
\hline Adj. $R^{2}$ & 0.00 & 0.13 & 0.14 & 0.14 \\
\hline Year FE & $\mathrm{NO}$ & $\mathrm{NO}$ & $\mathrm{NO}$ & YES \\
\hline
\end{tabular}

The sample includes both agents and CBs, which differ in business characteristics and size (with $\mathrm{CB}$ companies usually larger than agents' companies). Therefore, we now study the role of size for the two subsamples, respectively. Table 5 shows the results of regression (1) for the agents in each $\ln T A$ quintile. These allow us to examine the role of size as a performance driver for firms of different size classes, with columns (1) to (5) representing the smallest to the largest firm quintiles, respectively. We see that size, measured by $\ln T A$, is significant only for firms in the second and third $\ln T A$ quintiles. This finding suggests that firm size is a driver of profitability when an agent is not too small, but only up to a certain level, after which the firm's efficiency and business model become the dominant drivers.

Table 6 shows the results of a similar analysis for the $\mathrm{CB}$ subsample, but using size quartiles instead of quintiles to preserve a sufficient number of observations in each, since there are fewer CBs than agents. The results show that, in this case, size is not significant in any of the groups, and neither is the business model. This finding suggests that the dominant performance driver for CBs is the capacity for efficiency.

Table 5. Effects of size on agents

\begin{tabular}{|c|c|c|c|c|c|}
\hline & (1) & (2) & (3) & (4) & (5) \\
\hline \multirow{2}{*}{$\ln T A$} & 0.020 & $0.270^{* * *}$ & $0.245^{* * *}$ & 0.044 & 0.060 \\
\hline & {$[0.092]$} & [0.109] & {$[0.100]$} & {$[0.090]$} & {$[0.071]$} \\
\hline \multirow{2}{*}{$C O / I N C$} & $-0.472 * * *$ & $-0.646^{* * * *}$ & -0.790 *** & $-0.532 * * *$ & $-0.346^{* * * *}$ \\
\hline & [0.107] & {$[0.125]$} & {$[0.125]$} & {$[0.124]$} & {$[0.083]$} \\
\hline \multirow{2}{*}{$W S / S R V$} & -0.035 & -0.061 & -0.068 & 0.031 & $-0.148^{* *}$ \\
\hline & {$[0.060]$} & {$[0.040]$} & {$[0.050]$} & {$[0.061]$} & {$[0.057]$} \\
\hline \multirow{2}{*}{$D_{\text {รYехр }}$} & $0.698 * * *$ & -0.040 & 0.091 & -0.195 & 0.194 \\
\hline & {$[0.237]$} & {$[0.193]$} & [0.152] & {$[0.123]$} & {$[0.120]$} \\
\hline \multirow{2}{*}{$D_{\text {10Yехp }}$} & $0.676^{* * *}$ & -0.066 & 0.063 & $-0.182 *$ & $0.182^{* *}$ \\
\hline & [0.190] & [0.165] & [0.125] & {$[0.097]$} & {$[0.085]$} \\
\hline \multirow{2}{*}{$D_{\text {20Yexp }}$} & $0.769 * * *$ & -0.030 & 0.041 & $-0.117^{* * *}$ & $0.127^{* *}$ \\
\hline & {$[0.096]$} & {$[0.137]$} & {$[0.085]$} & {$[0.058]$} & {$[0.051]$} \\
\hline \multirow{2}{*}{$G D P$} & 1.117 & $-2.992 * *$ & 0.389 & $-2.205^{* * *}$ & -0.714 \\
\hline & [1.801] & [1.287] & [1.282] & [0.939] & [0.866] \\
\hline \multirow{2}{*}{ LNFM } & 1.961 & -1.063 & -0.435 & -1.697 & 3.114 \\
\hline & [4.621] & [3.239] & {$[2.626]$} & [1.944] & [2.055] \\
\hline \multirow{2}{*}{ Cost. } & -0.294 & -0.475 & -0.421 & 0.519 & -0.005 \\
\hline & {$[0.384]$} & {$[0.584]$} & [0.589] & [0.566] & [0.491] \\
\hline$N$ & 921 & 1,001 & 1,016 & 1,006 & 1,009 \\
\hline$R^{2}$ & 0.09 & 0.18 & 0.23 & 0.10 & 0.13 \\
\hline Adj. $R^{2}$ & 0.07 & 0.16 & 0.22 & 0.09 & 0.12 \\
\hline Year FE & YES & YES & YES & YES & YES \\
\hline YEARS & All & All & All & All & All \\
\hline FIRMS & $1 \mathrm{stQ} \ln \mathrm{TA}$ & $2 \mathrm{ndQ} \operatorname{lnTA}$ & $3 \mathrm{rdQ} \operatorname{lnTA}$ & 4thQ $\ln \mathrm{TA}$ & 5 thQ $\ln \mathrm{TA}$ \\
\hline
\end{tabular}

Note: $* p<0.1, * * * 0.05, * * * p<0.01$ 
Table 6. Effects of size on CBs

\begin{tabular}{|c|c|c|c|c|}
\hline & (1) & (2) & (3) & (4) \\
\hline \multirow{2}{*}{$\ln T A$} & 0.050 & 0.016 & -0.172 & 0.105 \\
\hline & {$[0.080]$} & {$[0.104]$} & {$[0.155]$} & {$[0.143]$} \\
\hline \multirow{2}{*}{ CO/INC } & $-0.351^{* \ldots * *}$ & -0.622 **** & 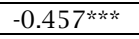 & $-0.508^{* * * *}$ \\
\hline & {$[0.092]$} & {$[0.107]$} & {$[0.143]$} & {$[0.145]$} \\
\hline \multirow{2}{*}{$W S / S R V$} & -0.074 & 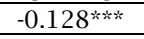 & -0.059 & -0.123 \\
\hline & {$[0.075]$} & {$[0.049]$} & [0.082] & {$[0.087]$} \\
\hline \multirow{2}{*}{$D_{\text {5Yехр }}$} & -0.095 & 0.080 & -0.088 & -0.105 \\
\hline & [0.198] & [0.093] & [0.169] & [0.150] \\
\hline \multirow[b]{2}{*}{$D_{\text {10Yехр }}$} & -0.092 & $0.090^{*}$ & -0.131 & -0.034 \\
\hline & {$[0.144]$} & [0.049] & [0.156] & {$[0.127]$} \\
\hline \multirow{2}{*}{$D_{\text {20үехр }}$} & 0.059 & & -0.146 & -0.008 \\
\hline & [0.095] & & {$[0.138]$} & {$[0.075]$} \\
\hline \multirow{2}{*}{$G D P$} & -2.333 & -0.874 & 0.653 & $-3.512^{* * *}$ \\
\hline & [1.763] & [1.327] & [1.247] & {$[1.254]$} \\
\hline \multirow{2}{*}{ LNFM } & 2.510 & -0.917 & -3.333 & $4.224 * *$ \\
\hline & [5.039] & [1.892] & [3.214] & [1.842] \\
\hline \multirow{2}{*}{ Cost. } & 0.152 & 0.573 & $1.768^{*}$ & -0.176 \\
\hline & [0.420] & {$[0.584]$} & [0.989] & [1.029] \\
\hline$N$ & 415 & 445 & 449 & 445 \\
\hline$R^{2}$ & 0.15 & 0.33 & 0.12 & 0.23 \\
\hline Adj. $R^{2}$ & 0.12 & 0.31 & 0.09 & 0.20 \\
\hline Year FE & YES & YES & YES & YES \\
\hline YEARS & All & All & All & All \\
\hline FIRMS & $1 \mathrm{stQ} \ln \mathrm{TA}$ & 2ndQ $\ln \mathrm{TA}$ & $3 \mathrm{rdQ} \ln \mathrm{TA}$ & 4thQ $\ln \mathrm{TA}$ \\
\hline
\end{tabular}

To test the robustness of our results, we repeat the analysis in equation (1), considering only those years before the new regulation's entry into force, to test whether the determinants of credit intermediaries' profits were consistent even before the reform. Table 7 shows the results. We see that the coefficients of size, efficiency, and the business model are still significant, with large absolute values.

Table 8 tests for indirect effects of Law 141. One could argue that the new regulation pushed credit intermediaries to increase in size or suffer from decreased profitability through higher costs. This does not seem to be the case, however, since, in Table 8 , we use size $(\ln T A)$, efficiency $(C O / I N C)$ and the business model (WS/SRV) as the dependent variables, and $D_{i, t}^{141}$ is not significant for any of them.

In the nontabulated analysis, we repeat the regression in the previous section, using the gross national income instead of the GDP to check if imports and exports, which vary over time, could create bias in the estimates. All the results are confirmed, even when the gross national income is used.

To test the robustness of the results, we also run a DiD regression using as the untreated group those agents and CBs that were operating before the new regulation was instituted but which did not enroll in the new registers. Table 9 reports descriptive statistics for the two groups before 2014 with 398 companies in the treated group and 190 in the untreated group. The variables for the two groups have similar values, on average, the only slight difference is that the firms in the untreated group are smaller and have lower salary costs.

Table 10 shows the results of DiD regression using the same regressor as in equation (1), except for $D_{144}$, which is substituted for by $\operatorname{did}_{141}$, a dummy that takes a value of one if the company is in the treated group and the observation is after 2013. The treatment effect is negative but not significant. In accordance with previous results, therefore, Law 141 does not appear to have a negative effect on enrollment in the OAM register.

Table 7. Robustness of the effects of Law 141 on sector profitability

\begin{tabular}{|c|c|}
\hline \multirow{2}{*}{$\ln T A$} & $0.078 * * *$ \\
\hline & {$[0.025]$} \\
\hline \multirow{2}{*}{$C O / I N C$} & $-0.733 * * *$ \\
\hline & {$[0.067]$} \\
\hline \multirow{2}{*}{$W S / S R V$} & $-0.066^{* *}$ \\
\hline & {$[0.031]$} \\
\hline \multirow{2}{*}{$D_{\text {5Yехр }}$} & $-0.190^{*}$ \\
\hline & {$[0.113]$} \\
\hline \multirow{2}{*}{$D_{\text {10Yехр }}$} & $-0.182 *$ \\
\hline & {$[0.106]$} \\
\hline \multirow{2}{*}{$D_{\text {20Yехр }}$} & -0.146 \\
\hline & {$[0.096]$} \\
\hline \multirow{2}{*}{$G D P$} & $-1.966^{* * * *}$ \\
\hline & {$[0.450]$} \\
\hline \multirow{2}{*}{$L N F M$} & $1.407^{* * * *}$ \\
\hline & {$[0.280]$} \\
\hline \multirow{2}{*}{ Cost. } & $0.527 * * *$ \\
\hline & [0.192] \\
\hline$N$ & 3,122 \\
\hline$R^{2}$ & 0.19 \\
\hline Adj. $R^{2}$ & 0.19 \\
\hline Year FE & YES \\
\hline YEARS & $<2013$ \\
\hline FIRMS & All \\
\hline
\end{tabular}


Table 8. Indirect effects of Law 141

\begin{tabular}{|c|c|c|c|}
\hline & $y=C O / I N C$ & $y=W S / S R V$ & $y=\ln T A$ \\
\hline \multirow{2}{*}{$D_{141}$} & 0.128 & 0.154 & -0.275 \\
\hline & [0.143] & [0.155] & [0.191] \\
\hline \multirow{2}{*}{$\ln T A$} & $-0.147^{\text {等* }}$ & $0.025^{*}$ & \\
\hline & {$[0.011]$} & {$[0.014]$} & \\
\hline \multirow{2}{*}{ CO/INC } & & $0.149 * * *$ & 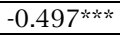 \\
\hline & & {$[0.024]$} & {$[0.038]$} \\
\hline \multirow{2}{*}{$W S / S R V$} & 0.081 **** & & $0.046 *$ \\
\hline & {$[0.013]$} & & {$[0.026]$} \\
\hline \multirow{2}{*}{$D_{\text {5Yехp }}$} & -0.031 & -0.026 & $0.184 * *$ \\
\hline & [0.050] & [0.052] & {$[0.091]$} \\
\hline \multirow{2}{*}{$D_{\text {10Yехp }}$} & -0.025 & 0.005 & $0.331^{\text {*** }}$ \\
\hline & [0.045] & {$[0.047]$} & {$[0.084]$} \\
\hline \multirow{2}{*}{$D_{\text {20Yехp }}$} & -0.022 & 0.022 & $0.184^{* * *}$ \\
\hline & [0.040] & [0.040] & {$[0.075]$} \\
\hline \multirow{2}{*}{$G D P$} & -0.413 & -1.296 & $6.861^{* * *}$ \\
\hline & [2.099] & {$[2.278]$} & [2.873] \\
\hline \multirow{2}{*}{$L N F M$} & 0.029 & $-0.266^{* * *}$ & -0.133 \\
\hline & {$[0.089]$} & [0.093] & [0.099] \\
\hline \multirow{2}{*}{ Cost. } & $1.694 * * *$ & 0.032 & $5.989 * * *$ \\
\hline & {$[0.132]$} & [0.156] & {$[0.173]$} \\
\hline$N$ & 6,737 & 6,737 & 6,737 \\
\hline$R^{2}$ & 0.11 & 0.03 & 0.11 \\
\hline Adj. $R^{2}$ & 0.11 & 0.02 & 0.11 \\
\hline Year FE & YES & YES & YES \\
\hline YEARS & All & All & All \\
\hline FIRMS & AGN & AGN & MED \\
\hline
\end{tabular}

Table 9. Descriptive statistics of the treated and untreated samples

\begin{tabular}{|l|c|c|c|c|c|c|}
\hline Treated & $\boldsymbol{N}$ & Mean & SD & Median & Max. & Min. \\
\hline ROE & 1,990 & 0.102 & 0.420 & 0.094 & 0.890 & -1.080 \\
\hline $\ln T A$ & 1,990 & 5.696 & 1.042 & 5.715 & 7.470 & 3.474 \\
\hline CO/INC & 1,990 & 0.947 & 0.237 & 0.926 & 1.942 & 0.584 \\
\hline WS/SRV & 1,990 & 0.368 & 0.414 & 0.230 & 1.833 & 0.000 \\
\hline Untreated & $\boldsymbol{N}$ & $\boldsymbol{M e a n}$ & $\boldsymbol{S D}$ & Median & Max. & Min. \\
\hline ROE & 950 & 0.114 & 0.480 & 0.094 & 1.200 & -1.333 \\
\hline lnTA & 950 & 5.397 & 1.308 & 5.340 & 7.788 & 2.398 \\
\hline CO/INC & 950 & 0.975 & 0.362 & 0.925 & 2.714 & 0.500 \\
\hline WS/SRV & 950 & 0.293 & 0.447 & 0.129 & 2.100 & 0.000 \\
\hline
\end{tabular}

Table 10. Descriptive statistics of the treated and untreated samples

\begin{tabular}{|c|c|}
\hline & $y=R O E$ \\
\hline \multirow{2}{*}{$\operatorname{did}_{141}$} & -0.021 \\
\hline & {$[0.028]$} \\
\hline \multirow{2}{*}{$\ln T A$} & $0.086 * 2 * *$ \\
\hline & {$[0.017]$} \\
\hline \multirow{2}{*}{ CO/INC } & $-0.411 *$ *** \\
\hline & {$[0.044]$} \\
\hline \multirow{2}{*}{$W S / S R V$} & $-0.070 * * *$ \\
\hline & {$[0.023]$} \\
\hline \multirow{2}{*}{$D_{\text {5Yехp }}$} & -0.044 \\
\hline & [0.069] \\
\hline \multirow{2}{*}{$D_{10 \text { Үехр }}$} & -0.046 \\
\hline & {$[0.058]$} \\
\hline \multirow{2}{*}{$D_{\text {20Yехp }}$} & -0.052 \\
\hline & {$[0.047]$} \\
\hline \multirow{2}{*}{$G D P$} & -0.676 \\
\hline & {$[0.507]$} \\
\hline \multirow{2}{*}{ LNFM } & $2.145^{* *}$ \\
\hline & {$[1.075]$} \\
\hline \multirow{2}{*}{ Cost. } & 0.099 \\
\hline & {$[0.115]$} \\
\hline$N$ & 5,292 \\
\hline$R^{2}$ & 0.12 \\
\hline Adj. $R^{2}$ & 0.12 \\
\hline Year FE & YES \\
\hline
\end{tabular}

\section{CONCLUSION}

Law 141 introduces new requirements for credit market operators in terms of capitalization and professionalism; furthermore, it creates a new specific authority, OAM, to supervise the sector, financed by fees applied to the operators themselves. The new rules for agents and CBs increased market entry barriers and required the investments of firms to be in compliance with the new regulation.

Our analysis shows that the entry into force of Law 141 is not associated with any change in the profitability of credit intermediaries. This results not allow to refute or support the two hypotheses proposed in Section 1: a negative effect of the entry in force of 141-law on firms' profits would had provided evidence that the new regulation's increased requirements for credit intermediaries resulted in higher costs and, on the other hand, a positive effect of the entry in force of 141-law on firms' profits would had demonstrated that the new market's regulation increased entry barriers or/and operator professionalism with the consequence of firms' income increase. The "no-effect" of regulation can mean two things: first, that the 141-law did not influence one of the previous elements, second, that the two effects on incomes and costs offset each other, with the ultimate consequence of no changing 
in profit of firms. Unfortunately, the available data and the chosen methodology limit the possibility to go any further but we can conclude that firms did not suffer from a 141-law entry in force and that their performance was mainly driven by firms' size, efficiency, and business model.

In particular, size is relevant only up to a certain level: after a company reaches a certain size, additional growth does not increase profitability. The evidence suggests that, although relevant, the investments necessary to comply with the new regulation do not increase costs in such a way that profitability is seriously hampered.

Furthermore, DiD analysis demonstrates that the new rules did not affect those firms that decided to continue as an agent or $\mathrm{CB}$ following the new requirements or those that exited the market. The absence of effect on exiting firms can be explained by the fact that the increase in market entry barriers introduced by Law 141 in 2013 rid the market of marginal players, that is, firms that, although having registered (in the BI register) as an agent/broker under the previous rules were only occasionally brokering loans and financial services.

Our analysis, however, has at least two limitations. First, we analyze only the Italian context, which is interesting for its strict application of Directive 2008/48/EC but could limit others. Second, the R-squared values in all the regressions are low, indicating that the model specifications could be better with other regressors; however, at this level of analysis, we cannot ensure that the econometric results would not change. These three aspects suggest that more research is needed to investigate the phenomena and test whether the regulation has a direct effect on firm performance.

\section{REFERENCES}

1. Alessandri, P., \& Bottero, M. (2017). Bank lending in uncertain times (Bank of Italy Temi di Discussione Working Paper No. 1109). https://doi.org/10.2139/ssrn.2964807

2. Ambrose, B. W., \& Conklin, J. N. (2014). Mortgage brokers, origination fees, price transparency and competition. Real Estate Economics, 42(2), 363-421. https://doi.org/10.1111/1540-6229.12039.

3. Bulow, G., Geanakoplos, J. D., \& Klemperer, P. D. (1985). Multimarket oligopoly: Strategic substitutes and complements. Journal of Political Economy, 93(3), 488-511. https://doi.org/10.1086/261312

4. Canales, R., \& Nanda, R. (2012). A darker side to decentralized banks: Market power and credit rationing in SME lending. Journal of Financial Economics, 105(2), 353-366. https://doi.org/10.1016/j.jfineco.2012.03.006

5. Cannari, L., Pagnini, M., \& Rossi, P. (Eds.). (2010). Banks, local credit markets and credit supply: Seminari e convegni workshops and conferences. Rome, Italy: Bank of Italy. Retrieved from https://ideas.repec.org/p/bdi /workpa/sec_5.html

6. Conklin, J. N. (2017). Financial literacy, broker-borrower interaction and mortgage default. Real Estate Economics, 45(2), 376-414. https://doi.org/10.1111/1540-6229.12140

7. Crossney, K. B. (2017). Who's at-risk? A case study of the demographic and socioeconomic characteristics of census tracts experiencing predatory and abusive mortgage lending in Philadelphia. Geoforum, 81(5), 129-413. https://doi.org/10.1016/j.geoforum.2017.02.013

8. De Muynck, M., \& Bruloot, D. (2017). Credit intermediation under the 2014 European Mortgage Credit Directive: A call for targeted rules on intermediary remuneration. European Review of Contract Law, 13(1), 1-37. https://doi.org/10.1515/ercl-2017-0001

9. Demyanyk, Y., \& Loutskina, E. (2016). Mortgage companies and regulatory arbitrage. Journal of Financial Economics 122(2), 328-351. https://doi.org/10.1016/j.jfineco.2016.07.003

10. Fu, X., Dong, M., Liu, S., \& Han, G. (2016). Trust based decisions in supply chains with an agent. Decision Support Systems, 82(2), 35-46. https://doi.org/10.1016/j.dss.2015.11.004

11. Gathergood, J. (2012). Self-control, financial literacy and consumer over-indebtedness. Journal of Economic Psychology, 33(3), 590-602. https://doi.org/10.1016/j.joep.2011.11.006

12. Gete, P., \& Gómez, J.-P. (2015). Compensation contracts and fire sales. Journal of Financial Stability, 18(6), 154-71. https://doi.org/10.1016/j.jfs.2015.04.002

13. Li, L. Y., Hermes, N., \& Meesters, A. (2019). Convergence of the performance of microfinance institutions: A decomposition analysis. Economic Modelling, 81(9), 308-324. https://doi.org/10.1016/j.econmod.2019.05.014

14. Mashamba, T. (2018). The effects of Basel III liquidity regulations on banks' profitability. Journal of Governance \& Regulation, 7(2), 34-48. http://doi.org/10.22495/jgr_v7_i2_p4

15. Moloi, T. (2014). Understanding banking regulatory and market framework in South Africa including the perceived strength, weaknesses, opportunities and threats. Journal of Governance and Regulation, 3(3), 34-43. http://doi.org/10.22495/jgr_v3_i3_p4

16. Pasiouras, F., Tanna, S., \& Zopounidis, C. (2009). The impact of banking regulations on banks' cost and profit efficiency: Cross-country evidence. International Review of Financial Analysis, 18(5), $294-302$. https://doi.org/10.1016/j.irfa.2009.07.003

17. Uchida, H., Udell, G. F., \& Yamori, N. (2012). Loan officers and relationship lending to SMEs. Journal of Financial Intermediation, 21(1), 97-122. https://doi.org/10.1016/j.jfi.2011.06.002

18. Del Prete, S., Pagnini, M., Rossi, P., \& Vacca, V. (2017). Lending organization and credit supply during the 2008 09 crisis (Working paper No. 1108). Rome, Italy: Bank of Italy. Retrieved from https://ideas.repec.org/p/bdi /wptemi/td_1108_17.html

19. Wei, X., Gong, Y., \& Wu, H.-M. (2017). The impacts of Net Stable Funding Ratio requirement on Banks' choices of debt maturity. Journal of Banking \& Finance, 82(9), 229-243. https://doi.org/10.1016/j.jbankfin.2017.02.006 